\title{
Horizontality of Fundamental Rights in Bangladesh*
}

\author{
Ridwanul Hoque \\ Professor, Department of Law, University of Dhaka, Bangladesh
}

\begin{abstract}
The High Court Division on the application of any person aggrieved, may give such directions or orders to any person or authority, including any person performing any function in connection with the affairs of the Republic, as may be appropriate for the enforcement of any of the fundamental rights conferred by Part III of this Constitution [The Constitution of Bangladesh, art. 102(1)].
\end{abstract}

\section{INTRODUCTION ${ }^{1}$}

Since the advent of $21^{\text {st }}$ century, the scope of the constitutional guarantees of rights so as to reach into the private sphere ("horizontal" impact) has been one of the "the most fundamental issues in constitutional law'. ${ }^{2}$ The issue also emerged and continues to be 'one of the most important and hotly debated in comparative constitutional law', ${ }^{3}$ with some leading global jurisdictions adopting the theory of horizontal applicability of constitutional rights. ${ }^{4}$

In Bangladesh, the public-law-style adjudication has still a long way to go. 'Public law' refers to a system of law that aims at the greater public good, piercing the narrow public-private divide when the enforcement of public responsibilities and constitutional values is in question. A modern function of public law is to exercise control over private power, especially when private entities deal with the citizens' rights and entitlements in a way that transcends the nature of private transactions. ${ }^{5}$ When constitutional values such as the primacy of human rights are at stake, it is important to extend the clutch of constitutionalism over private entities. In this context, three issues come to the fore. Firstly, whether private entities discharging functions of

* This paper is an extended and adapted version of a paper earlier presented at a BILIA seminar on constitutional law. See Ridwanul Hoque, 'Horizontality of Fundamental Rights in Bangladesh: A Tale of Discordance between the Text and the Judicial Say', paper read at the Bangladesh Institute of Law and International Affairs (BILIA), Dhaka, 8 December 2012. I sincerely thank Dr. Shahdeen Malik, Dr. Naim Ahmed, and the participants of the seminar for their insights and suggestions. I would like specially to thank Lokman Bin Nur at the University of Asia Pacific Law School for his kind and able research assistance for this paper.

1 For this section, I have heavily relied on my following previous work: Ridwanul Hoque, Judicial Activism in Bangladesh: A Golden Mean Approach (Cambridge Scholars Publishing 2011).

2 See Stephen Gardbaum, 'The "Horizontal Effect" of Constitutional Rights' (2003) 102(3) Michigan Law $\operatorname{Rev} 387$.

Ibid, 387 .

4 Among these countries are Ireland, Canada, Germany, South Africa, the United Kingdom (after some initial hesitation) and India from South Asia. It should be noted that the USA considers constitutional rights enforceable only against "state actions".

5 See, for example, Paul Craig, 'Public Law and Control Over Private Power' in M Taggart (ed), The Province of Administrative Law (Hart Publishing 1997) 196. 
public nature, such as a private school imparting education to children, can be forced to bear the human rights-responsibilities or 'public' duties under the Constitution. Secondly, when fundamental rights are directly breached by private entities or persons, can constitutional remedies be issued against such a body or person? Thirdly, away from the enforcement consideration, can a private person or a corporation be expected to respect the fundamental rights of the people? The latter issue is related to the concept of constitutional morality in that one is expected, by moral standards, to obey the constitutional norms, although there is no remedy for the person wronged when that expectation (the moral urge) is broken. This paper does not deal with this concept.

This paper is concerned with the second consideration above, and it investigates the question of (direct and indirect) horizontality of fundamental rights, which essentially is the question of whether constitutional rights can be enforced against non-state actors or private entities. Generally, 'the horizontal application of human rights to non-state actors [...] is an evolving and contested legal area both comparatively and at the international level'. ${ }^{6}$ However, as noted, the horizontality of fundamental rights in Bangladesh is constitutionally envisaged. Nevertheless, although the Court in Bangladesh extended the meaning of public authority to include relatively new public agencies as subjects of judicial review on the ground of principle of legality under art. $102(2),{ }^{7}$ a matter that falls within the first consideration above, it has so far virtually refused to enforce fundamental rights against private actors including those exercising functions of public nature. The horizontal application of judicial review on the principle of legality under art.102(2), based on a liberal interpretation of 'public' or 'statutory' authorities, is what is known as the statutory horizontality (of human rights) in the UK. ${ }^{8}$ For our purpose, this phenomenon can be termed as interpretive horizontality. Unlike in the UK, interpretive horizontality under art. 102(2) is distinct from horizontal judicial review on the ground of breaches of fundamental rights under art. 102(1).

In Mainul Hosein v Anwar Hossain (2006), ${ }^{9}$ the High Court Division quite clearly acknowledged that fundamental rights can be enforced against private individuals and other private juristic persons. ${ }^{10}$ Unfortunately, however, the Appellate Division

6 Aoife Nolan, 'Holding Non-state Actors to Account for Constitutional Economic and Social Rights Violations: Experiences and Lessons from South Africa and Ireland' (2014) 12(1) International Journal of Constitutional Law 61, 61.

7 See e.g. Mrs. Farzana Muazzem v Securities and Exchange Commission [2002] 54 DLR 66 (HCD); Conforce Ltd v Titas Gas Co. Ltd [1992] 42 DLR 33 (HCD) (a company of a public corporation or one working in the affairs of a statutory local body is a public authority). A definition of statutory public authority has been provided in article 152 of the Constitution.

8 'Statutory' horizontal effect arises 'as a result of the courts' interpretive obligation under s 3 HRA': Phillipson and Williams, note 13 below, at 878. Section 3 of HRA provides that laws should be interpreted in a way that is compatible with the "Convention rights" incorporated by the Act. This happens basically by way of interpreting what a 'public authority' is under s 6 of the HRA. See, e.g., X v Y [2004] EWCA Civ 662; YL v Birmingham City Council [2007] UKHL 27 (taking a narrow approach to "public authority").

9 [2006] 58 DLR $117 \& 157$ (HCD).

10 [2006] 58 DLR 157 (HCD) [161] (Aziz J, the third judge, endorsing Mamun J who disagreed with Abedin $\mathrm{J}$ in the earlier split decision).

Page $\mid 56$ 
overruled this rights-enhancive decision in Anwar Hossain v Mainul Hosein (2006), ${ }^{11}$ by invoking the old reasoning that the concerned private person charged for rightsviolation (here, the right to freedom of press) was not connected with the affairs of the Republic. Although the Appellate Division took a technical stance of not saying enough on the issue of consequences of violation of fundamental rights, its decision seems to have a voided both the letter and the spirit of art. 102(1) vis-à-vis the horizontal application of fundamental rights.

Several years after the Appellate Division's decision in the above case, the High Court Division in two cases of judicial review against private bodies forcefully observed that in appropriate cases private actions breaching constitutional rights are judicially reviewable. Despite the High Court Division's recognition in at least three cases of the horizontal impact of fundamental rights under the Constitution, an absence of a precedent from the Appellate Division operates as a setback.

There has recently been an interesting development in the area of public law compensation - the Court issuing compensation directives against private entities such as bus companies or private health clinics or hospitals. This remedy is certainly covered within the ambit of art. 102(1) of the Constitution which enables the Court to issue any "order" in the enforcement of fundamental rights. As such, issuing compensation orders against private persons can probably be considered a form of horizontality of fundamental rights. In none of these compensatory decisions, however, had the Court ever penned down any reasoning revealing that they were enforcing fundamental rights. In fact, the Court issued constitutional remedies in claims of common law tort nature. Therefore, the Court's compensatory jurisprudence, some scholars argue, remains unprincipled. ${ }^{12}$ It is not within the scope of this paper to discuss this development.

Below, the paper first provides a brief introduction to the concept of horizontality. Thereafter, some court cases under the rubric of 'indirect horizontality' are analysed, to briefly portray the judicial discourse of horizontality. Next, this paper analyses the decision in which the question of direct horizontality of fundamental rights received a judicial treatment at the High Court Division. It then seeks to draw comparative insights from India and Sri Lanka, and the concluding part concludes the paper.

\section{THE CONCEPT OF HORIZONTALITY AND THE CONSTITUTION}

At the outset, the important distinction between the two ideas of horizontality, the direct and the indirect horizontality, should be made clear. As Gardbaum observed, human rights take a "direct" horizontal effect "if they are vindicated by a cause of action vested against private persons', whereas their "indirect" horizontal effect takes place

11 [2006] 58 DLR 229 (AD), [2007] 15 BLT 144 (AD).

12 Ridwanul Hoque and Sharowat Shamin, 'Bangladesh: State of Liberal Democracy' in Richard Albert et al. (eds), 2017 Global Review of Constitutional Law (I-CONnect and the Clough Center for the Study of Constitutional Democracy 2018) 28, 31-21. For a critique of public law model of ordinary torts in South Asia generally, see Rehan Abeyratne, 'Ordinary Wrongs as Constitutional Rights: The Public Law Model of Torts in South Asia’ (2018) 54(1) Texas International Law Journal 1. 
when those rights apply 'not to private persons but only to existing law'. ${ }^{13}$

The concept of direct horizontality signifies that any constitution being the embodiment of the value of basic human rights should be applicable against not only state authorities (vertically) but also against private juristic and natural persons. On the other hand, "indirect horizontality" refers to the use of human rights to develop common law $^{14}$ or the wider principles of constitutionalism. Here the idea is that, irrespective of whether human rights can be applied against any private person or not, every person should take into consideration seriously the mandates of human rights in making decisions. This can be explicated by referring to the idea, for example, that all private companies in Bangladesh must abide by the constitutional principle of nondiscrimination while hiring or firing people for their organization. The most notable reflection of indirect horizontality is the enforcement of fundamental rights against private persons through the medium of the state by requiring it to take actions to protect the citizens against violations in the private sphere.

I now turn to the provisions of the Constitution to look into the status of the doctrine of horizontal application of fundamental rights. Article 102, clause (1), of the Constitution, reads as follows:

The High Court Division on the application of any person aggrieved, may give such directions or orders "to any person or authority", including any person performing any function in connection with the affairs of the Republic, as may be appropriate for the enforcement of any of the fundamental rights conferred by Part III of this Constitution.

The above text makes it clear that the Constitution envisaged the judicial enforcement of fundamental rights against "any person or authority", including one in the affairs of the Republic. This the Court can do by issuing any "appropriate" directions or including an appropriate writ-order as mentioned in art. 102(2). However, whether a particular right can be horizontally applied depends on whether any private person is charged with an obligation to comply with that right. In this respect, it should be noted that the phrases of rights clauses in the Constitution are differently couched, making some rights either directly horizontal or indirectly horizontal while leaving some rights as not horizontal. ${ }^{15}$ Some rights are phrased in such a way that omits to mention who the persons the 'order/prohibition' in those rights seeks to cover.

Article 28(1) reads as follows: 'State shall not discriminate against any citizen [...]', while article 27 says that, 'all citizens are [...] entitled to equal protection of law'. The equality right, thus, seems to be indirectly horizontal as there is no mention of the State in art. 27. So do articles 32 (the right to life and liberty) and 35(5) ("no person shall be

13 G Phillipson and A Williams, 'Horizontal Effect and the Constitutional Constraint' (2011) 74(6) MLR 878, 881, citing S Gardbaum, 'Where the (State) Action Is' (2006) International Journal of Constitutional Law 760, 764.

14 On this, see Murray Hunt, 'The Horizontal Effect of the HRA' [1998] Public Law 423.

15 For a further analysis, made in the Indian context, see Sudhir Krishnaswamy, 'Horizontal Application of Fundamental Rights and State Action in India' in C R Kumar and K Chockalingam (eds), Human Rights, Justice, and Constitutional Empowerment (Oxford University Press 2007) 47-73.

Page $\mid 58$ 
subjected to torture'). On the other hand, article 34 that prohibits forced labour seems to have an effect of direct horizontality as the offence/wrong of forced labour is more likely to be committed by private persons. In People's Union for Democratic Rights $v$ Union of India (1982) ${ }^{16}$ involving the breach of article 23 of the Indian Constitution (prohibiting human trafficking), which is equivalent to article 34 of the Bangladeshi Constitution, the Indian Supreme Court held that article 23 of their Constitution was applicable against private persons.

In Bangladesh, there almost is an absence of a discourse of the horizontality of constitutional rights and norms. By contrast, some seem to refute the idea of constitutional horizontality in Bangladesh. The eminent constitutional lawyer, Mahmudul Islam wrote that 'the Constitution seeks to delineate the powers and functions of the important branches of the government, the relationship between those branches and the relationship of the government with the individuals and the Constitution does not in the remotest way seek to define the relationship between individuals so that the question of an individual seeking to enforce a fundamental right against another individual does not arise' (emphasis supplied). ${ }^{17}$

This is a rigid position, somewhat akin to the American argument that the Constitution is enforceable against state actions only, and the view does not come in terms with the idea of the Constitution as a living organism. Islam reasons that, although the expression - 'give such direction or orders to any person or authority, including any person performing any function in connection with the affairs of the Republic' - in art. 102(1) may create an impression that fundamental rights are enforceable against any private person or body, that is not the case. His contention is that art. 102(1) should not be interpreted in isolation, and that each and every expression in the Constitution should be interpreted with regard being paid to the context. He borrows support for his argument from art. 26, which speaks of the possibility of violation of fundamental rights by a law in that the clause provided that parliament shall make no law in derogation of fundamental rights. Islam's contention is that an individual cannot be adversely affected without the means of law, so any such person can challenge the legality of the law itself under article 102(2).

This, again, is a restricted view of the value of fundamental rights. ${ }^{18}$ While article 26 refers to law while thinking of the possibility of rights-violation, article 44 contemplates any action (and not 'the law' alone) that may also be a tool with which to interfere with fundamental rights. In a recent case discussed below, Mr. Islam as an amicus curia submitted that "it is a given that judicial review of an act of a private entity which is neither a statutory nor a local authority is not permissible under the Constitution". ${ }^{19}$ Another lawyer in that case, however, took an opposite view

\footnotetext{
People's Union for Democratic Rights v Union of India [1982] AIR 1473 (SC).

Mahmudul Islam, Constitutional Law of Bangladesh (3rd edn, Mullick Brothers 2012) 608.

18 Islam, ibid, has not commented on the SCAD's decision in Anwar Hossain v Mainul Hosein [2006] 58 DLR (AD) 229, nor on the HCD's decision in Mainul Hosein.

19 Hakim v Bangladesh, noted below in note 35 (quoted from Ahmed J's opinion at 132, [4]).
} 
supporting horizontal judicial review of private body actions, with whose approach the Court agreed. ${ }^{20}$

\section{INDIRECT HORIZONTALITY IN BANGLADESH}

It seems that human rights in Bangladesh are given an indirect horizontality effect. However, the jurisprudence that clearly recognizes the applicability of fundamental rights against private actors is absent in Bangladesh. Judicial conservatism in expanding remedies in cases involving actions of private parties was reflected in Sultana Nahar v Bangladesh (1998). ${ }^{21}$ In this case, certain sex-workers were evicted by the locals and a lawyer filed a writ petition seeking directions in the protection of this unfortunate group of people. The Court not only refused standing to a lawyer but also held that constitutional remedies were unavailable against the illegality committed by private parties.

Intriguingly, the Sultana Nahar Court let a legal wrong go un-redressed only because private parties were involved, although the petitioner in fact sought remedies against the government's failure to protect the citizens whose rights were infringed by private actors. Moreover, a narrow constitutional construction in Sultana Nahar led to a failure in appreciating that horizontality of fundamental rights was clearly envisioned in article 102(1) read with article 44 of the Constitution. The Court's reasoning is akin to a 1956 Indian Supreme Court case in which it was held that, 'as a rule[,] constitutional safeguards are directed against the state and its organs and that protection against violation of rights by the individuals must be sought in the ordinary law. ${ }^{22}$

This is, however, not to discredit certain remedial innovations that were sought to be issued against private persons. In ASK v Government of Bangladesh (2003) ${ }^{23}$ involving deaths from fire-accidents in some garments factories, the HCD instructed the commercial banks not to advance loans to any garments industry if it could not show, to its credit, a safety fitness certificate. In Md. Kamal Hossain, BLAST \& Others $v$ Bangladesh (2005), ${ }^{24}$ involving deaths and injuries of many workers from the collapse of a garments factory building in Savar, the HCD sought to increase the victims' chance of compensation by issuing an injunction against responsible company's attempt to dispose of its property. In these cases, however, the court did not explain the legal basis of its action against private persons including banks.

In addition to this kind of judicial orders against private persons, which is tantamount to recognizing indirect horizontality, there are certain examples of judicial review

20 Mr. Rokanuddin Mahmud's view. Ibid.

21 [1998] 18 BLD 361 (HCD), a decision by a third judge, Rahman J, agreeing with Ameen J. The other judge of the split-court, $M$ Hoque J, beautifully rebutted objections to the public interest standing of the petitioner and allowed her to stand for those 'poor, neglected, wretched, unfortunate, downtrodden, hated, homeless and helpless'.

22 Vidya Verma v Dr Shiv Narain Verma [1956] AIR 108 (SC).

23 [2003] 4 CHRLD 147 (CHRLD = Commonwealth Human Rights Law Digest).

24 [2005] WP No. 3566 (High Court Division).

Page $\mid 60$ 
petitions (writs) against non-state actors. Khondaker Modarresh Elahi v Bangladesh $(2001)^{25}$ is a case in point. Although it refused the remedy that was asked, the Court went very close to establishing the horizontality of constitutional rights when it issued a rule nisi against political parties calling for an explanation as to why hartal should not be declared unconstitutional. ${ }^{26}$ Earlier, in 1995, another hartal-challenging writ was filed against a private person, Ms. Sheikh Hasina, the then Chief of the Oppositions. The court, however, did not accept the petition. ${ }^{27}$ In India, the Kerala High Court, and later the Supreme Court of India, ruled that calling for and holding of a bundh (hartal) is unconstitutional as it violates the constitutional fundamental rights of the citizens. ${ }^{28}$ The Court, on the application of two citizens belonging to the Kerala Chambers of Commerce, applied fundamental rights against a private entity, a political party.

In an interesting development in 2003, the High Court Division in Zakir Hossain Munshi v Grameen Phone (2003) ${ }^{29}$ allowed a judicial review, based on the principle of legality under article 102(2), against the Bangladeshi leading private cellular phones provider, Grameen Phone, to prevent it from unlawfully levying extra charges on subscribers. The case did not involve the violation of fundamental rights, but rather the question of legality or the due process of law. The long-standing principle that a writ does not lie against a private person was somewhat relaxed here on the ground that the company was a "licensee of the government". Perhaps the court wanted to extend the meaning of 'public function', but its reasoning was based on inadequate doctrinal analyses and lacked articulation of fundamental rights and public law elements involved therein. For example, it is still a puzzling question whether the Grameen Phone or any other private company is a licensee of government functions within the meaning of article 102(2). ${ }^{30}$ And, even if it was, the Court did not come to any finding as to whether any fundamental right was breached by the company. The case, thus, seems to be not a case that would squire with article 102(1).

In a 2010 decision in Rokeya Akhtar Begum v Bangladesh, the HCD observed that fundamental rights can be enforced against private bodies and that judicial review is maintainable against a private body if it performs the functions in connection with the affairs of the Republic or a 1ocal authority. ${ }^{31}$ It also held that the source of power is not the sole test to identify whether a body is subject to judicial review. Rather, it is the functional test that may bring a private action within the purview of constitutional judicial review. The Court did not find any violation of fundamental rights by the relevant respondent or a performance of any function in connection with the affairs of

25 [2001] 21 BLD 352 (HCD).

${ }^{26}$ In refusing to deliver the remedy, the Court reasoned that 'this political issue should in all fairness be decided by the politicians'. Ibid, [375] (Aziz J).

${ }^{27}$ Abu Bakar Siddique v Sheikh Hasina [1995] WP No. 2057 (High Court Division).

${ }^{28}$ Bharat Kumar K Palicha $v$ State of Kerala [1997] AIR 291(Kerala); Communist Party of India (Marxist) v Bharat Kumar [1998] AIR184 (SC).

${ }^{29}$ [2003] 55 DLR 130 (HCD) (Abedin J).

${ }^{30}$ It is interesting that, the judge of this liberal decision was in Mainul Hosein against the view that fundamental rights can be enforced against private companies.

${ }^{31}$ Rokeya Akhtar Begum v Bangladesh [2018] 6 CLR 206 (HCD) (decision of 8 June 2010, per A H M Shamsuddin Chowdhury J). 
the republic.

In Begum, an acting principal of the Viqarunnisa Noon School and College sought to stop the appointment of a regular principal by challenging the legality of publishing an advertisement by the College governing body. The core issue was whether the College authorities were a public authority to be amenable to judicial review under art. 102(2) based on the principle of legality. It was not a case of judicial review under art. 102(1) on the ground of breach of fundamental rights. The Court, however, observed that 'when fundamental rights are relied on, the question of the status of the impugned person or authority loses [its] relevance because [of] the phrase[] "any person or authority" [in art. 102(1)]'.32 At another place, the Court commented in passing that "in appropriate cases' a body like Diabetic Association, for example, may be very well found to be 'in breach of fundamental rights so as to render it prone to [judicial] review under Article 102(2) and (1) respectively'. ${ }^{33}$

Begum probably shows that the Court was otherwise ready to direct horizontal application of fundamental rights if it were a fit case. Apparently, by applying that 'function-based test', the Court could not give relief exclusively under article 102(2) if fundamental rights were violated by a private entity. ${ }^{34}$ The remedies would then have to be issued under art. 102(1) combined with remedies under art. 102(2).

In a 2013 decision in which judicial review was successfully extended over an impugned action of a public nature by a private entity, the High Court Division in a forceful obiter emphatically held that breaches of fundamental rights by private entities are subject to judicial review under art. 102(1). In Moulana Md. Abdul Hakim v Bangladesh ${ }^{35}$ the principal of a private educational institute (madrasa) successfully challenged his dismissal by the management committee. ${ }^{36}$ In the Court's view, a claimant can seek judicial review under article 102(1) or/and article 102(2) 'depending on the nature of the grievance'. In its own words,

Article 102(1) sets itself apart from article 102(2)(a)(ii) [writ of certiorari] by bringing within its purview a wider group of individuals and authorities on whom the Court may on judicial review hold sway. When issues of fundamental rights are raised, the sanction under article 102(1) is clearly of


public functions for the purposes of judicial review based on the principle of illegality under art. 102(2). It is different from Begum in that the Abdul Hakim Court not only assessed whether the functions of the concerned private entity were of a public nature, it also applied judicial review horizontally and provided detailed reasoning. The Court applied the function-test, and observed that certain private actors such as education and health-sector institutes do perform functions that may essentially belong to 'the public domain' (per Syed Refaat Ahmed J). For an analysis of this case, see Ridwanul Hoque, 'The "Datafin" Turn in Bangladesh: Opening Up Judicial Review of Private Bodies' (Administrative Law in the Common Law World, 25 October 2017) <https://adminlawblog.org/2017/10/25/ridwanul-hoque-the-datafin-turn-in-bangladesh-opening-upjudicial-review-of-private-bodies/> accessed 24 November 2021.

Page $\mid 62$ 
availability of redress against "anyone," or "any authority", inclusive of "any person performing any function in connection with the affairs of the Republic". The reference to government functionaries [in art. 102(2)] must, accordingly, be seen as an appendage made to the broader category of "anyone" or "any authority" [in art. 102(1)] by way of abundant caution. ${ }^{37}$

The novelty in Abdul Hakim is that the Court considered article 102(1) "relevant" for "the purpose" of the case, although it was on an ultimate analysis a challenge on the basis of the principle of legality/illegality per art. 102(2). The decision also suggests that when acting under art. 102(1), the writs under art. 102(2) would be of help. Abdul Hakim along with Begum thus helpfully open the most needed discourse of blending horizontal enforcement of fundamental rights with the Court's writ-jurisdiction and horizontal enforcement of judicial review on grounds of 'illegality' of actions.

\section{DIRECT HORIZONTALITY: A FAILED CASE}

In Abdul Hakim and Begum, the horizontality of fundamental rights was not vindicated by the petitioners. A remedy of direct horizontality was successfully sought in Mainul Hosein v Anwar Hossain at the HCD level. On appeal, the Appellate Division avoided making any decision on direct horizontality.

The facts of the case that involved decisions of both Divisions of the Supreme Court are that Mr. Anwar Hossain, who became a Minister in 1996 under the consensus government of the Awami League, continued as the second executive director and also the printer, publisher, and editor of the Daily Ittefaq. Mr. Hossain, by exercising the power of his public office, later terminated the services of two employees and appointed an editor in-charge of the Daily. In such circumstances, the petitioner, Mr. Mainul Hosein challenged the legality of the Minister's holding a public post and taking part in the management of a private company (the Daily Ittefaq) and also the legality of the measures taken by him against the employees of the company. Two arguments advanced were that article 147(3) of the Constitution, which sought to avoid conflict of Ministers' public duty and private interest, was breached and the actions by the respondent, while he was a minister, resulted in the breach of the fundamental right of freedom of press (depriving the petitioner and the members of the public of an opportunity to read objective and fair news). Here, we are concerned solely with the second contention.

\section{A. Mainul Hosein v Anwar Hossain (2006) ${ }^{38}$}

Interestingly, until the decision in this case the remedial potential of article 102(1) of the Constitution remained beyond the judicial gaze. Rather, as noted above, the Court was rather oblivious of the impact of art. 102(1).

In Mainul Hosein, the High Court Division delivered a split-decision. Justice Abedin discharged the rule while Justice Mamun made it absolute and held that fundamental rights can be enforced against private persons. Upon hearing, the third judge, Justice Aziz, concurred with Justice Mamun.

37 [2014] 34 BLD 129 (HCD) 133 [12].

38 [2006] 58 DLR 117 (HCD). 
No matter how the arguments of the counsels were couched, but it seems that this case invoked a fundamental rights claim against a private person, since the actions challenged were actions not by a Minister per se. But a significant issue of the exercise of public power in disguise was at stake. It was claimed that a Minister in the first place cannot hold a post of profit in a company. Second, the Minister decided as a private person but by exerting his public position. The case nevertheless appears to be a difficult one for the purposes of analysis in that the court's main concern was not the enforcement of fundamental rights. In the two writ petitions that were filed against the respondent, ${ }^{39}$ no prayer was indeed made seeking to enforce fundamental rights. It was only during the hearing of the cases that the petitioners' lawyers adopted a strategy to increase the possibility of winning by mounting a claim that the petitions 'should be taken to have been filed under Article 102(1)'.

Abedin $\mathrm{J}$, the senior judge of the Bench handing down the split decision, did not consider that the fundamental right of freedom of press was indeed implicated in this case. The other judge, Mamun J, did not in fact comment on this point with reasoning, but he appreciably held that article 102(1) speaks of any private person against whom an order can be issued.

Abedin $\mathbf{J}$ considered the claim of violation of fundamental rights as frivolous, and quoted the Appellate Division's observation in Mujibur Rahman v Bangladesh that the Court should always remain alert to the possibility of misusing the instrumentality of article 102(1) to litigate ordinary legal violations. In Mujibur Rahman, the SCAD held that ' $[\mathrm{t}]$ he Court is $[\ldots]$ to be on guard so that the great value of the right given under Article 102(1) is not frittered away or misused as a substitute for more appropriate remedy available for an unlawful action involving no infringement of any fundamental right. ${ }^{40}$ This observation of the SCAD may be interpreted as an indication of judicial readiness to enforce fundamental rights against private persons (although the case where this observation was made was filed against the Republic).

On the other hand, Mamun J took the view that the facts of the writ petitions combined issues of fundamental rights and the constitutional mandate as to public offices and found the petitions to be maintainable. As he reasoned, article 102(1) is a continuation of article 44 that guarantees for every citizen a right to enforce fundamental rights. By interpreting the words 'any person or authority including any person performing any function in connection with the affairs of the Republic' in art. 102(1) and by putting emphasis on the word 'including', he held that there are two categories of people against whom the Court may issue directions or orders. In the $1^{\text {st }}$ category are people who are 'any person or authority'. Second, there are people who are "persons" 'performing any function in connection with the affairs of the Republic'. ${ }^{41}$ The limitation of this holding, however, is that it lacked doctrinal analyses including, for example, an analysis of the intention of the framers of the Constitution or of the global

39 There were 3 petitions, each in 1996, 1997 and 1999, of which 2 were directly against Mr. Anwar Hossain.

40 Mujibur Rahman v Bangladesh [1992] 44 DLR 111 (AD).

41 [2006] 58 DLR 117 (HCD) [141].

Page $\mid 64$ 
developments on this matter.

The third judge, Aziz J, by relying on comparable Indian decisions accepted the argument that, Mr. Hossain cannot but be a person interfering with the press freedom as guaranteed under article 39(2)(b). ${ }^{42}$ As he held, '[i]t cannot be said in absolute terms that, the writ petitions are not maintainable against a private individual and no declaration or direction can be given by this Court in exercise of jurisdiction under Article 102' ${ }^{43} \mathrm{He}$ further found that Mr. Hossain's activities as a private person combined with his position as a minister vis-à-vis the newspaper invariably affects the freedom of the petitioner and the members of the public to read impartial and fair news. $\mathrm{He}$, therefore, thought that 'there is no bar' in exercising the power of judicial review 'under article 102'. ${ }^{44}$

It is interesting that the judge did not cite clause (1) of art. 102, but rather cited art. 102 as a whole. He was probably interpreting the function of a private person who was a minister at the same time as having come under the mischief of "public duties", although there is an absence of reasoning in this regard. The fact remains that, this judge too did not unambiguously hold that fundamental rights are enforceable against private persons. His reticence on direct horizontality can be read out from his reliance on an Indian case, Shri Anadi Trust $v$ VR Rudani ${ }^{45}$ in which the Indian Supreme Court favoured the expansion of constitutional remedies in order to extend 'judicial control over the fast-expanding maze of bodies affecting the rights of the people ${ }^{46}$ and that a positive direction ("mandamus") should be available to remedy any injustice whenever found. Aziz J did not rely on any Indian case in which fundamental rights were directly applied or where the Court held them to be horizontally applicable.

\section{B. Anwar Hossain v Mainul Hosein (2006) ${ }^{47}$}

Upon appeal, the Appellate Division overruled the High Court Division's decision in Mainul Hosein. The Appellate Division, it seems, took a very technical stance. It simply held that a writ petition against a person in his capacity of Executive Director and publisher of a private publication company is not maintainable. The Appellate Division mainly remained confined to the issues of the breach of art. 147(3) and whether a writ could issue against a private person under art. 102(2).

The Appellate Division did not in effect take up the issue of judicial enforcement of fundamental rights against a private entity under article 102(1) that mentions 'any person'. On the maintainability of the writ petitions due to a breach of article 39 (freedom of expression), the Appellate Division made the following reticent comment:

\footnotetext{
In all the three opinions, the judges cited 9 Indian cases and 1 Pakistani case.

[2006] 58 DLR 157 (HCD) [162].

Ibid, [167].

[1989] AIR 1607 (SC).

Ibid. The quotation appears at 161. The Court also referred to D Basu's book on Indian constitutional law in which Basu made the claim that Indian Constitution's phrase 'any person or authority' in article 226 (equivalent to art 102(1) of the Bangladeshi Constitution) covers 'any person or body performing public duties even though such duties may not be imposed by law'. [2006] 58 DLR 229 (AD).
}

47 
'taking into consideration the arguments put forward by the learned Counsels for both [..] parties and the decisions cited above, we are of the opinion that [the writ petitions] are not maintainable on this count also' ${ }^{48}$ Only one of the cases the Court cited involved the invocation of the ground of breach of fundamental rights, which cautioned against the misuse of art. 102(1) as a substitute for a remedy against 'an unlawful action involving no infringement of any fundamental right'. ${ }^{49}$ Moreover, the Court left it unclear whether art. 39 was found to be violated at all and held that the writ petitions turned infructuous in the wake of the appellant's end of ministerial tenure.

The Appellate Division seems to have taken the stance that abstract theoretical questions are of only academic importance and are not to be decided by any court. ${ }^{50}$ But the issue was not simply an academic one. In the HCD, three judges differed from each another on the point of horizontal impact of fundamental rights under art. 102(1). The Appellate Division's silence as regards the distinctness and horizontality of art. 102(1), therefore, arguably operates against constitutional originalism, especially in view of an express intention of the framers that the constitutional fundamental rights would be enforceable not only against state actions but also against private functions. A restrictive interpretation of art. 102(1) would run counter to a liberal or purposive interpretation of the text $\mathrm{t}^{51}$ as well as the principles of human dignity and respect for human rights as enshrined in the preamble of the Constitution.

\section{COMPARATIVE SCENARIO}

It is encouraging that the expansion of constitutional remedies against private entities is indeed a growing tendency at the global level including in South Asia, although judicial approaches to the rights-horizontality are not uniform. ${ }^{52}$ In this section, we focus on the horizontality of human rights in India and Sri Lanka, but it would be useful to briefly capture the developments from the UK and Germany that are, respectively, of common law and civil law traditions.

A notable development tied with the expansion of remedies is the horizontal extension of judicial review over private agencies/individuals whose activities generate publiclaw consequences, or which violate fundamental rights. In the UK, where direct horizontality has not been mandated, some scholars support direct horizontality of human rights in accordance with the Human Rights Act 1998 (HRA) ${ }^{53}$ Until recently,

\footnotetext{
Ibid, [236].

Mujibur Rahman v Bangladesh [1992] 44 DLR 111 (AD).
}

50 This is an observation made in Kudrat E Elahi Panir v Bangladesh [1992] 44 DLR 319 (AD). In the High Court Division, the counsels of the respondent urged the Court to adopt this position, which Mamun J refused to take.

51 On this, see, among others, Aharon Barak, Purposive Interpretation in Law (Princeton University Press 2005).

52 For comparative insights into rights-horizontality, see Mark Tushent, 'The Issue of State Action/Horizontal Effect in Comparative Constitutional Law' [2003] 1 International Journal of Constitutional Law 79; Andrew Clapham, Human Rights Obligations of Non-state Actors (OUP 2006).

53 An early work on this issue is W Wade, 'Horizons of Horizontality' (2000) 116 LQR, 217. See also Ian Leigh, 'Horizontal Rights, the Human Rights Act and Privacy: Lessons from the Commonwealth' (1999) 48 ICLQ 57; G Phillipson, 'The Human Rights Act, "Horizontal Effect" and the Common Law: Bang or a Whimper?' (1999) 62(6) MLR 824.

Page $\mid 66$ 
however, the UK judiciary, remained relatively reluctant in enforcing rights horizontally under the HRA. ${ }^{54}$ One reason for this reluctance was the absence of an express mandate for the horizontality of human rights. Another reason is the common law approaches to remedies that can be had against private entities and public bodies. Traditionally, in the UK, 'ultra vires' has always been considered a foundational ground of judicial review. After the enactment of HRA, the UK judiciary and scholars are increasingly speaking of a 'constitutional foundation' (rather than common law foundation) of judicial review. ${ }^{55}$ As such, they are now more open to the enforcement of fundamental rights against private persons. Yet, there is no consensus 'on the nature and extent of the courts' duty to give horizontal effect' to human rights incorporated in the HRA $1998 .{ }^{56}$

Human rights are enforced horizontally also by the European Court of Human Rights, which offers significant evidence that at the international plane human rights are no more seen as exclusively applicable against the state actions. ${ }^{57}$ Regarding the question of whether a constitution should extend protection of individual rights against non-state actors, Germany has lately adopted an interesting solution. In Germany, constitutional protection of fundamental rights extends generally to transactions among private parties but in an indirect way and on a case-by-case basis, a practice of "indirect direct" applicability that, however, blurs the divide between vertical and horizontal legal relationships. ${ }^{58}$ Germany initially was in favour of strictly "indirect" effect of constitutional rules. In a 1958 case (the Lüth case), the German Federal Constitutional Court held that constitutional rules do not control, but merely 'influence the development of the private law'. ${ }^{59}$ The indirect applicability approach has been greatly reshaped by the recently developed concept of 'protective duties' of the State. ${ }^{60}$ According to this concept, developed by the Federal Constitutional Court in a 1975 case involving the rights of a fetus, ${ }^{61}$ 'the basic rights impose upon the state not merely a negative duty to avoid certain actions, but a positive duty to take action so that the citizen does in fact enjoy the basic rights promised in the Constitution'. ${ }^{62}$ The

54 See Jones v University of Warwick [2003] 1 WLR 954; Campbell v MGN Ltd [2004] UKHL 22.

55 Mark Elliott, Constitutional Foundations of Judicial Review (Hart Publishing 2006).

56 Phillipson and Williams, above note 13, at 878 (advocating a 'constitutional constraint model' that supports the Court's incremental implementation of horizontality of human rights).

57 I Ziemelle, Human Rights Violations by Private Persons and Entities: The Case Law of International Human Rights Courts and Monitoring Bodies (EUI Working Paper No. AEL 2009/8).

58 See Norman Dorsen et al., Comparative Constitutionalism: Cases and Materials (2d edn, West Academic Publishing 2010) 896 (discussing German Basic Law "third-party effect" or “Drittwirkung"); Jud Mathews, Extending Rights' Reach: Constitutions, Private Law, and Judicial Power (OUP 2018) (discussing how courts make choices about whether, when, and how to give rights horizontal effect in three case studies of Germany, the United States, and Canada).

59 Greg Taylor, 'The Horizontal Effect of Human Rights Provisions, The German Model and Its Applicability to Common-Law Jurisdictions' (2002) 13(2) King's LJ 187, 188.

60 On this, see R Brinktrine, 'The Horizontal Effect of Human Rights in German Constitutional Law: The British Debate on Horizontality and the Possible Role Model of the German Doctrine of mittelbare Drittwirkung der Grundrechte', [2001] 4 Eur H Rts LR 421.

61 BVerfGE 39,1 (BVerfGE = Bundesverfassungsgericht $=$ Federal Constitutional Court) (noted in Taylor (n 59) 205.

62 Taylor (n 59) 205. 
consequential effect of this approach is that constitutional rules/rights can be horizontally applied against and between private persons and entities in certain circumstances. This position is something that is more liberal than the strictly indirect approach to the impact of constitutional rights or norms. In two recent decisions which involved 'stadium ban' and 'hotel ban' by private parties, for example, the German Federal Constitutional Court held that although fundamental rights do not establish directly binding obligations between private actors, according to the doctrine of indirect horizontality they nevertheless 'constitute an objective order of constitutional values (objektive Wertordnung) which must be respected in all areas of law'. ${ }^{63}$ The Court reiterated, writes Schultz, that 'in certain circumstances, the right to equality will indeed take effect between private parties: for instance, where an event is open to a large audience and where the exclusion from such event significantly affects the ability of the excluded person to participate in social life, the party organising the event has a special legal responsibility under Art. 3(1) [of the German Basic Law]' ${ }^{64}$

\section{A. Horizontality of fundamental rights in India}

In South Asia, rights-horizontality has occurred in India, Sri Lanka, and Nepal as a public law expansion of constitutional remedies. The lead is taken by the Indian courts which have "travelled a great deal from the limited notion that fundamental rights are available only against the state. ${ }^{65}$ Indian top courts have enforced, not infrequently, the fundamental values of human rights against both recalcitrant corporations and private individuals. ${ }^{66}$ They have provided 'fundamental rights' with both direct and indirect horizontal effect by imposing a wider range of constitutional duties on state actors and by accommodating private actors as respondents to writ petitions. ${ }^{67}$

The trajectory of rights-horizontality can be shown by citing an old case. In 1996, the Indian Supreme Court in Bodhisattwa Gautam v Subhra Chakraborty ${ }^{68}$ ordered an accused person, who was facing a criminal trial in the court below, to pay compensation to a rape-victim for violating her right to life. After 30 years into this decision, the Court in Vishaka $v$ State of Rajasthan ${ }^{69}$ emphatically held that all citizens are amendable to a constitutional obligation under article 51A of the Indian Constitution not to engage in sexually discriminatory behavior in the workplace. By this, the Court meant that private persons are subject to an obligation not to breach fundamental rights.

The Indian Supreme Court has since enforced fundamental rights against corporations and private individuals in several cases, without providing any deeper reasoning

63 Alix Schulz, 'Horizontality and the Constitutional Right to Equality- Recent Developments in the Jurisprudence of the German Federal Constitutional Court' (OxHRH Blog, November 2019), $<$ http://ohrh.law.ox.ac.uk/horizontality-and-the-constitutional-right-to-equality-recent-developments-

64 Ibid.

65 Jeewan Reddy and Rajeev Dhavan, 'The Jurisprudence of Human Rights' in D M Beatty (ed), Human Rights and Judicial Review: A Comparative Perspective (Martinus Nijhoff 1994) 175, 194.

66 See, e.g., Kapila Hingorani v State of Bihar [2003] SCCL 472 (Com).

67 Krishnaswamy (n 15).

68 [1996] 1 SCC 490.

69 [1997] AIR 3011 (SC).

Page $\mid 68$ 
though. In cases involving the prohibition of non-discrimination (art. 15) and the abolition of untouchability (art. 17), it was held that fundamental rights are enforceable against private persons violating those rights. In a 1995 case, the Court allowed a writ petition for the protection of the right to life of workers against the employer, and observed as follows:

in an appropriate case, the Court would give appropriate directions to the employer, be it the State or its undertaking or-private employer to make the right to life meaningful; to prevent pollution of work place; protection of the environment; protection of the health of the workman or to preserve free and unpolluted water for the safety and health of the people. The authorities or even private persons or industry are bound by the directions issued by this Court under Article 32 and Article 142 of the Constitution. ${ }^{70}$

In another famous case, the Indian Supreme Court horizontally enforced the right to education against private schools. ${ }^{71}$ The majority court held that private schools can be made bound to apply a $25 \%$ quota to be reserved for disadvantaged students. The constitutional validity of the Right of Children to Free and Compulsory Education Act 2009 was challenged by an association of unaided private schools on the ground of violation of the (enforceable) right to profession and business. The Court held that the Act's fundamental aim was to realize the fundamental right to education and, thus, it was applicable to 'an unaided non-minority school not receiving any kind of aid or grants to meet its expenses from the appropriate Government or the local authority'. It, however, made a reservation for non-application of the quota requirement for minority private schools, as it would otherwise violate article 30 of the Indian Constitution. ${ }^{72}$

Analysing the judgement entirely on technical grounds, especially in light of the dissenting opinions, one could probably say that the Court in this case did not actually deal with the horizontal effect of fundamental rights, but rather decided the question of whether or not the impugned Act was constitutional. Such a line of argument would, however, ignore the spirit of the relevant constitutional provisions. Eventually, it cannot be gainsaid that in all constitutional cases a court indeed decides the constitutionality of any law or the action/inaction that is challenged.

\section{B. Horizontality of fundamental rights in Sri Lanka}

In the late 1970s, the Sri Lankan judiciary viewed fundamental rights as being in operation 'only between individuals and the State', and thereby suggesting an inability to enforce human against private persons. ${ }^{73}$ This approach began to change gradually, and the change came through expansion of public law's control over private entities that are closed tied with 'state actions'. ${ }^{74}$

\footnotetext{
Consumer Education \& Research v Union of India [1995] AIR 922 (SC) [30] (Ramaswamy J).

Society for Un-aided Private Schools of Rajasthan v Union of India [2010] Writ Petition No. 95.

On this, see, e.g., Stephen Gardbaum, 'The Indian Constitution and Horizontal Effect' (conference on the Oxford Handbook of the Indian Constitution, New Delhi, 2014) <http://ssrn.com/ abstract $=2601155>$.

73 Rienzie Perera v University Grants Commission [1978-80] 1 Sri LR 128.

74 See, for an analysis, Mario Gomez, 'The Modern Benchmarks of Sri Lankan Public Law' (2001) 118 South African Law Journal 581.
} 
At the outset, it should be noted that the Sri Lankan Constitution 1978 only recognizes that fundamental rights can be infringed only by an executive or administrative action, and not by a private action. Article 126(1) gives the Supreme Court an exclusive jurisdiction to hear and determine any question relating to the infringement or imminent infringement by executive or administrative action of any fundamental right recognized by the Constitution.

In Ariyapala Gunaratne v The People's Bank (1986), the Supreme Court of Sri Lanka recognized that 'the ambit of the fundamental rights has a much wider range. ${ }^{75} \mathrm{It}$ emphasised that article 12(3) of the Sri Lankan Constitution - the principle of nondiscrimination based on race, religion, and so on - 'contemplates possible violations of fundamental rights even by private individuals.' Thus, 'fundamental rights are not infringed only by executive or administrative action[s,] but go beyond the provisions of Article $126,{ }^{76}$ The Court applied the fundamental right to join trade unions against a private bank that barred its employees from participating in any union or union activities. $^{77}$

In the year following Ariyapala Gunaratne, the Sri Lankan Supreme Court lifted the corporate veil of a private company to test whether the action of the Air Lanka Ltd. was an administrative action or not. In a two-to-one majority decision, the Court applied the 'function'-test and found the activities of the company as a public function. ${ }^{78}$ It then extended the doctrine of 'state action'/'administrative action' to enforce the fundamental right to form or join associations against a corporation. In its own words,

The juristic veil of corporate personality donned by the company' for certain purposes cannot, for the purposes of the application and enforcement of fundamental rights enshrined in Part III of the Constitution; be permitted to conceal the reality behind it which is the government. ${ }^{79}$

It seems that the Sri Lankan Supreme Court in this case applied the theory of indirect horizontality by progressively interpreting the scope of "state power" or "state action". ${ }^{80}$ The development has mainly taken place through a broadening of the meaning of administrative action based on the function-based test. The approach is essentially the act of 'blending rights with writs' ${ }^{81}$ through the mechanism of direct

\footnotetext{
[1986] SLSC, LEX/SLSC/0008/1986.

Ibid, [42].

77 A district court had granted the same right, but the court of appeal reversed the judgement. Later, the Supreme Court restored the judgment of the district court.

78 Rajaratne v Air Lanka Ltd and Others [1987] SLSC, LEX/SLSC/0018/1987.

79 Ibid, [19].

80 Some years earlier, in Velmurugu $v$ the Attorney-General and Another [1981] SLSC, LEX/SLSC/0030/1981 [89] two judges in the minority commented that 'trampling underfoot the fundamental freedoms' by law-enforcement officers should not be tolerated, but the judges did not suggest any private person's obligation to respect fundamental rights. This was a case against a lawenforcement officer for violation of fundamental rights, which failed for what the court said the lack of proof.

81 Mario Gomez, 'Blending Rights with Writs: Sri Lankan Public Law’s New Brew' (2006) 45 Acta Juridica 451.
}

Page $\mid 70$ 
horizontality of judicial review based on the principle of legality when a breach of fundamental rights is alleged. ${ }^{82}$ An innovative approach was, for example, taken in a 2016 case in which an action by a private company owned by the Sri Lankan Ports Authority was held to be accountable for the breach of fundamental rights of its employees. $^{83}$

\section{CONCLUSION}

This paper has shown that the discourse of horizontal impact of fundamental rights has emerged in Bangladesh only recently, despite the fact that the Constitution quite innovatively envisaged the concept as long back as 1972. Although the High Court Division has recognised the horizontality of fundamental rights under art. 102(1), there is not a single case in which rights have directly been enforced against private entities. As seen in some cases above, there is a limited practice of indirect horizontality of fundamental rights, but the Court offered no reasoning for imposing duties on private entities.

The paper reveals that the adjudication of constitutional rights in Bangladesh is still deficient in globality consciousness. Horizontality of human rights has turned out to be a progressive trend in global practices of constitutionalism. In India, as seen above, the Court is applying constitutional rights against private individuals and entities although the Indian Constitution lacks express recognition of such horizontality. And, in Sri Lanka, where the Constitution rather limits the enforcement of constitutional rights only against state actions, the Court devised the remedial tool of indirect horizontality of rights.

It seems that the decision of the Appellate Division in Anwar Hossain will likely have negative consequences for human rights jurisprudence for some years. By resorting to the theory of judicial economy or restraint, the SCAD in Mainul Hosein took an unnecessarily reticent position which by implication undervalues the words and spirit of arts. 44 and 102(1) of the Constitution. Admittedly, Mainul Hosein was not a fit litigation on the question of horizontal application of fundamental rights. It can nevertheless be argued that the SCAD took the concept of horizontality of fundamental rights quite wrong. By relying on a conservative decision on this point by the Indian Supreme Court, the Appellate Division seems to have downplayed the very constitutional text in art. 102(1) on direct horizontality of constitutional rights.

Adjudication of human rights should be seen in the context and through the lens of the legal culture of any given society. In Bangladesh, we often ignore and forget the primacy of 'duty' in the legal system/culture and the adjudicative framework. ${ }^{84}$ Bangladesh's legal system is basically duty-based and 'clearly posited on societal

82 See Harjani v Indian Overseas Bank [2005] 1 Sri LR 167 where the court held private bodies exercising public functions amenable to the writ of certiorari. See also Lanka Viduli Podu Sevaka Sangamaya v Ceylon Electricity Board [2019] SLCA, LEX/SLCA/0259/2019.

83 Captain Channa Abeygunewardena v Sri Lanka Ports Authority [2017] SLSC, LEX/SLSC/0014/2017 (rejecting an objection on the ground of contractual nature of the respondent's employment).

84 See, for details, Hoque, Judicial Activism in Bangladesh (n 1) 99-100. 
duties and public obligations', ${ }^{85}$ an aspect that is not often appreciated in the literature and judicial discourses. It is embedded in society that the violator of rights, be it a private person or the government, must be held to account.

In today's globalized world, many private entities are dealing with the lives and rights of citizens in a substantive way, which was unthought-of even a decade ago. Constitutionalism demands that fundamental rights should in principle be enforceable against the fast-growing private sphere that tends increasingly to intrude into the rights of the citizenry. The theory of effective remedy, which is an obligation under the international human rights instruments, also demands horizontality of human rights. In adjudicating fundamental rights, the Court should therefore adhere to the principles of respect for human rights or civil liberties, legality, and human dignity. ${ }^{86}$

85 Ibid, 99 (by referring to art. 21 of the Constitution that imposes a duty on every citizen to observe the law and the Constitution and to fundamental state policy principles that impose a duty on the state to establish social justice).

86 Borrowed from Conor Gearty, Principles of Human Rights Adjudication (OUP 2004).

Page $\mid 72$ 